\title{
Bi-Variate Causality between States per Capita Income and State Public Expenditure - An Experience of Gujarat State Economic System
}

\author{
Dr. S. A. Saiyed*
}

\begin{abstract}
This paper is a study of Bi-variate causality between State Per Capita Income and State Public Expenditure in Gujarat State Economic System during the Post Economic Reforms period from 1991 to 2005. First, impact of State Per Capita Income on State Public Expenditure in Gujarat State is investigated and then influence of State Public Expenditure on State Per Capita Income in Gujarat State is examined during 1991 to 2005. Here in this study time series is used to examine the relationship between year-wise State Per Capita Income and State Public Expenditure in Gujarat State, for the study years 1991 to 2005 . Our Two Variables Regression analysis showed significant Bi-variate causal relationship between year-wise number of State Per Capita Income and State Public Expenditure in Gujarat State Economic System.

Key Words: Bi-variate, causality, State Per Capita Income, State Public Expenditure, Two Variables Regression
\end{abstract}

\section{Introduction}

The study of causality between State Per Capita Income and State Public Expenditure in Gujarat State Economic System has attracted the interest of many economists and policy makers for a very long period of time in world as a whole, both at theoretical and empirical levels. In most of the developed and developing countries the debate is going on about causal relationship between State Per Capita Income and State Public Expenditure. It is very important to investigate if there is any Bi-variate causal relationship between these two variables State Per Capita Income and State Public Expenditure.

Wagner's Law States that Public Expenditure plays no crucial role in Growth of National Income, Per Capita Income, State Gross Domestic Product and State Per Capita Income, i.e. increase in State Public Expenditure does not increase National Income, Per capita income, State Gross Domestic Product and State Per Capita Income. .

Wagner (1883) predicted that Economic Growth i.e. increase in National Income, would increase Public Expenditure. Thus, the causality according to Wagner's law is running from National Income, Per Capita Income, State Gross Domestic Product and State Per Capita Income, to State Public Expenditure i.e. increase in National Income, Per Capita Income, State Gross Domestic Product and State Per Capita Income, increase State Public Expenditure. On the other side, Keynesian hypothesis support that the causality is running from State Public Expenditure to National Income, Per Capita Income, State Gross Domestic Product and State Per Capita Income, which is in contrast with Wagner's law.

Our study is for Post Economic Reforms period from 1991 to 2005. After New Economic Reforms in Gujarat State Economic System in 1990-91 due to Globalization and Liberalization many changes have taken place. State Per Capita Income and State Public Expenditure have expanded. Therefore it is necessary to examine Bi-variate causal relationship between State Per Capita Income and State Public Expenditure in Gujarat State Economic System.

The remainings of the paper is organised into nine sections including earlier introduction. Section two presents theoretical foundation of the study, Section three describes the objectives of study, Section four is about hypotheses, and Section five describes methodology and model specification. Section six, is about sources of data, Section seven, reviews literatures. The empirical findings are reported in Section eight, Section nine presents conclusion.

\section{Theoretical Foundation}

Economic Growth means increase in real State Per Capita Incomeand Per Capita Income of the country over a long period of time. This increase in State Per Capita Incomeand Per Capita Income enables the country to increase State Public Expenditure for the welfare and higher standard of living of the people Some Economists like Wagner argue that increase in State Per Capita Incomeand Per Capita Income leads to increase in Public Expenditure. Thus, National Per Capita Income and State Per Capita Income are independent variables and National and State State Public Expenditure are Dependent Variables. State Per Capita Income and Per capita income are the causes and State Public Expenditure is the effect. Different Economists have different feelings about relationship between State Per Capita Income and Per capita Income on Public Expenditure. 
Wagner expounded that the "Law of increasing expansion of public and particularly state activities" which is referred to as the "Law of increasing expansion of fiscal requirements". The Law suggests that the share of the public sector in the economy will rise as State Per Capita Income and Per capita Income increase, owing to the intensification of existing activities and extension of new activities. According to Wagner, social progress has led to increasing state activities with resultant increase in Public Expenditure.

As against this some Economists like Keynes, believe that increase in State Public Expenditure increases State Per Capita Income and Per Capita Income which gives rise to Economic Growth. Keynes has propounded only one theory i.e., the theory of State Public Expenditure (theory of investment), which made him the greatest economist of the $20^{\text {th }}$ century. This is the pivotal theory around which all theories are developed by Keynes' cluster. In other words, all the economic doctrines are the direct offshoot of the theory of investment. The theory of government expenditure was proved to be more successful in fighting the ill effects of Great Depression. According to Keynes increase in National and State Public Expenditure, i.e. increase in Investment in Public Sector increases State Per Capita Income and State Per Capita Income in multiplier way. Thus, according to Keynes, State Public Expenditure is independent variable and increase in State Per Capita Income is dependent variables.

Thus, Wagner's law and the Keynesian theory present two opposite perceptions in terms of the relationship between National and State Per Capita Income and National and State Public Expenditure. According to Wagner's approach causality runs from Per Capita Income to State Public Expenditure and the Keynesian approach assumes that causality runs from State Public Expenditure to State Per Capita Income. Actually both the perceptions are valid in case of Gujarat State Economic System during the period of 1991 to 2005.

Thus, it becomes necessary to investigate Bi-variate causal relationship between State Per Capita Income and State Public Expenditure. In this study we have found out that both State Per Capita Income and State Public Expenditure influence each other. Both State Per Capita Income and State Public Expenditure are interdependent and exogenous and endogenous to each other in Gujarat State Economic System.

\section{Objectives Of The Study}

The main objective of this paper is to examine Bi-variate causal relationship between State Per Capita Income(SPICG), and State Public Expenditure(SPEXG). We want to empirically analyze the effect of State Per Capita Income on State Public Expenditure and influence of State Public Expenditure on State Per Capita Income in Gujarat State Economic System during 1991 to 2005.

\section{Hypotheses Of The Study}

The present paper aims at determining empirical Bi-variate causal relationship between State Per Capita Income and State Public Expenditure in Gujarat State Economic System. We have the following important hypotheses:

(1) There is Bi-variate causal relationship between State Per Capita Income and State Public Expenditure in Gujarat State Economic System.

(2) State Per Capita Income has increased State Public Expenditure in Gujarat State Economic System. State Per Capita Income in Gujarat State Economic System is exogenous and State Public Expenditure Gujarat State Economic System is endogenous.

(3) Increase in State Public Expenditure in Gujarat State Economic System has increased State Per Capita Income in Gujarat State Economic System. State Public Expenditure is exogenous and State Per Capita Income in Gujarat State Economic System is endogenous.

\section{Methodology Of Analysis}

In this paper, empirical analysis is undertaken with a view to establish Time Series Bi-variate causal relationship between State Per Capita Income and State Public Expenditure in Gujarat State Economic System for the period from 1991 to 2005 by using computer software (E-views). This has been carried out with the help of year-wise secondary data.

This paper has been designed so as to examine the hypotheses as mentioned earlier in this study.

Here, statistical regression model is employed as a tool for the analysis of relationship between the variables which we are predominantly concerned with. The dependent variable in Model-1 is the year-wise State Public Expenditure (in Rs. Crores) over15 years in Gujarat State Economic System. On the other hand, the independent variable is State Per Capita Income in Gujarat State Economic System (SPCIG) at constant prices. In Model-II the dependent variable is the year-wise State Per Capita Income in Gujarat State Economic System (SPCIG) (in Rs. Crores) at constant prices and independent variable is State Public Expenditure in Gujarat State Economic System (in Rs. Crores) 
We have estimated two variable models and then fitted double natural logarithmic (log) equations below with the corresponding statistical values of student's t-statistics, $\mathrm{R}^{2}, \mathrm{R}^{2}, \mathrm{~F}$-value, D-W Statistics and the regression coefficients.

\section{Sources Of Data}

The sources of data are exclusively built on secondary survey. The required statistical data are collected from various sources, and have been used for analysis purpose, and they are from the following sources:

(1) Budgets of Gujarat State Government

(2) Reserve Bank of India (RBI), CSO..

And also data collected from other reliable sources.

\section{Review Of Literature}

Many studies have been carried out in many countries as well as Indian Economy and Gujarat State Economic System which are of greater significance. Among a few significant studies on impact of National Income, State Per Capita Income on State Public Expenditure and effects of State Public Expenditure on State Per Capita Income, we have reviewed following works on Gujarat Economic System:

Indira examines that Gujarat has a relatively high per capita income, a diversified economy and workforce and developed financial and capital markets. On the other hand, the state lags behind in terms of the quality of employment and several dimensions of human development. This research seeks to delineate the profile of Gujarat's development with a view to understanding the mixed results and inferring the likely directions of future development.

Ravindra Dholakia stated that the development strategy in Gujarat has been very clear since its inception in 1960 in according a high priority to industrialization. The impact of economic liberalisationon the state economy should, therefore, be examined in terms of the performance

of industrialization in the state.

Mathur,Niti and Kashyap provides a statistical profile of pre-and post green revolution agriculture in Gujarat. Changes in cropping pattern has been shifting in favour of non-traditional non-food crops. Gujarat needs investment in infrastructure and strategies for sustainable resource

use to improve productivity in agriculture.

Jammejay Singh and Parmesh Shah observed that the public sector of most developing countries is often the target of numerous criticism - lack of or no infrastructure, absenteeism of service providers like teachers and doctors, poor quality of services, corruption, non transparency, favoritism, discrimination, etc. While several of these criticisms are usually attributed to lack of resources and the conflict between the needs of equity and those of efficiency, research has shown in general that the correlation between increased public expenditure and actual outcomes or improvements in service delivery is weak. This gap between spending and development outcomes reflects on more serious deficiencies of 'voice' and 'accountability' for citizens in general, and the poor in particular. This study argues that participatory public expenditure management (PPEM) provides a set of such mechanism.

Though this is not an exhaustive survey of the literature that has gone into this area, we feel that it does provide analytical framework for enabling us to undertake the present study.

\section{Retsuls And Discussion}

In this paper the time series data of State Per Capita Income (SPCIG) and State Public Expenditure (SPEXG) in Gujarat State Economic System for the study years 1991 to 2005 is estimated by fitting the double natural logarithmic ( $\log )$ relationship. In this study, there are Two Models. In Model-I, year-wise total number of State Per Capita Income (SPCIG) is independent variables and State Public Expenditure ( SPEXG) is dependent variable. In Model-II, year-wise total number of State Public Expenditure( SPEXG) is independent variables and State Per Capita Income (SPCIG) is dependent variable. We have obtained the following results by examining the Bi-variate Causal Relationship in both the Models.

\subsection{TWO VARIABLES REGRESSION MODELS}

Regression estimates as mentioned earlier in this chapter for period from 1991 to 2005 is presented with Two Variables Regression Model with both dependent and independent variables in natural logarithmic (Log) equations below one after another in both the Models, Model-I and Model-II 


\subsubsection{Model I}

\section{Model: Log SPEXG $=\alpha+\beta_{1} \log$ SPCIG $+\mu_{1}$}

Where SPEXG stands for Total number of State Public Expenditure in Gujarat State Economy year-wise is a dependent variable and SPCIG stands for State Per Capita Income in Gujarat State Economy as independent variable.

Model-I

\begin{tabular}{|l|r|r|r|r|}
\hline \multicolumn{4}{|c|}{ Dependent Variable: LOG(SPEXG) } \\
\hline Variable & Coefficient & Std. Error & t-Statistic & Prob. \\
\hline C & 4.200393 & 1.545865 & 2.717181 & 0.0176 \\
\hline LOG (SPCIG) & 0.460790 & 0.161229 & 2.857991 & 0.0134 \\
\hline R-squared & 0.985869 & Mean dependent var & 8.604610 \\
\hline Adjusted R-squared & 0.938628 & S.D. dependent var & 0.582474 \\
\hline S.E. of regression & 0.473696 & Akaike info criterion & 1.467062 \\
\hline Sum squared resid & 2.917038 & Schwarz criterion & 1.561469 \\
\hline Log likelihood & -9.002967 & F-statistic & 8.168110 \\
\hline Durbin-Watson stat & 2.073772 & Prob(F-statistic) & 0.013449 \\
\hline
\end{tabular}

\section{Source: Author's own calculation}

\section{LOG $($ SPEXG $)=4.20039326+0.4607902749 *$ LOG $($ SPCIG $)$}

The above regression results support the fact that the relationship between State Per Capita Income (SPCIG) and State Public Expenditure in Gujarat State Economy (SPEXG) is significant and positive as shown by the student's t-values attached to it. The slope signifies that for the study years 1991 to 2005, year-wise number of State Per Capita Income (SPCIG) has positive influence on the determination of State Public Expenditure year-wise. Coefficient of "State Per Capita Income (SPCIG)" also indicates that for Rs. 1 crores changes in the "State Per Capita Income (SPCIG)", the "Public Expenditure" would change by Rs. 0.4607 crores. $\mathrm{R}^{2}$ is significant which shows that year-wise number of "State Per Capita Income (SPCIG)" is an important factor and explains 98\% of variations in State Public Expenditure in Gujarat State Economic System. F-value is highly significant which shows positive relationship between the variables for the whole result. Thus, State Per Capita Income (SPCIG) actually has positively influenced State Public Expenditure in Gujarat State Economic System. D-W statistics indicates almost absence of auto-correlation among the residuals.

From the above analysis, we can conclude that the State Per Capita Income (SPCIG) is significant and has positive influence on State Public Expenditure in Gujarat State (SPEXG). This regression results confirm to our Hypothesis No.2 as stated earlier in this paper.

\subsubsection{Model-II}

\section{Model-II: Log SPCIG $=\alpha+\beta_{1} \log$ SPEXG $+\mu_{1}$}

Where, SPCIG stands for Total number of State Per Capita Income in Gujarat Economic System is an independent variable and SPEXG stands for Total number of State Public Expenditure in Gujarat Economic System year-wise is dependent variable. And $\mathrm{u}_{1}$ stands for error terms.

Model-II

\begin{tabular}{|l|r|r|r|r|}
\hline \multicolumn{4}{|c|}{ Dependent Variable: LOG (SPCIG) } \\
\hline \multicolumn{1}{|c|}{ Variable } & Coefficient & Std. Error & t-Statistic & Prob. \\
\hline C & 2.352409 & 2.526581 & 0.931064 & 0.3688 \\
\hline LOG(SPEXG) & 0.837406 & 0.293005 & 2.857991 & 0.0134 \\
\hline Adjusted R-squared & 0.985869 & Mean dependent var & 9.557963 \\
\hline S.E. of regression & 0.918628 & S.D. dependent var & 0.785223 \\
\hline Sum squared resid & 0.638581 & Akaike info criterion & 2.064429 \\
\hline Log likelihood & 5.301210 & Schwarz criterion & 2.158835 \\
\hline Durbin-Watson stat & -13.48321 & F-statistic & 8.168110 \\
\hline
\end{tabular}

\section{Source: Author's own calculation}

\section{LOG(SPCIG) $=\mathbf{2 . 3 5 2 4 0 9 4 4 3}+\mathbf{0 . 8 3 7 4 0 6 2 2 2 5} *$ LOG(SPEXG)}

The above regression results supports the fact that the relationship between State Public Expenditure and State Per Capita Income (SPCIG) in Gujarat Economy System is significant and positive as shown by the student's t-values attached to it. The slope signifies that for the study years 1991 to 2005, year-wise number of State Public Expenditure has positive influence on the determination of State Per Capita Income (SPCIG) yearwise. Coefficient of "State Public Expenditure" also indicates that for Rs. 1 crore changes in the "State Public Expenditure" would change State Per Capita Income (SPCIG) by Rs. $\mathbf{0 . 8 3 7 4}$ crores. $\mathrm{R}^{2}$ is significant which 
shows that year-wise number of "Public Expenditure" is an important factor and explains 98\% of variations in State Per Capita Income (SPCIG). F-value is highly significant which shows positive relationship between the variables for the whole result. Thus, Public Expenditure actually has positively influenced State Per Capita Income (SPCIG). D-W statistics indicates almost absence of auto-correlation among the residuals.

From the above analysis, we can conclude that the State Public Expenditure is significant and has positive influence on State Per Capita Income in India in Gujarat Economy System. This regression results confirm to our Hypothesis No.3 as stated earlier in this paper.

\section{Concluding Remarks}

Our results of Regression Analysis of Model-I reveal that State Per Capita Income (SPCIG) in Gujarat Economy System has significant and positive influence on the determination of State Public Expenditure for the study years 1991 to 2005.Thus our analysis supports our Hypotheses No. 2 as stated in the paper. Our results of Regression Analysis of Model-II reveal that State Public Expenditure in Gujarat Economy System is also an important determinant of State Per Capita Income (SPCIG) in Gujarat Economy System. This analysis also supports our Hypothesis No.3 as stated in the paper. Thus, both State Per Capita Income (SPCIG) and State Public Expenditure in Gujarat Economy System are interdependent and therefore there is a Bi-variate causal relationship between State Per Capita Income (SPCIG) and State Public Expenditure in Gujarat Economy System. Both these variables are exogenous as well as endogenous to each other. Our Empirical results show that in our Model-I in which, State Per Capita Income (SPCIG) is independent variable, $\mathbf{R}^{\mathbf{2}}$ is $\mathbf{0 . 9 8}$ and $\mathbf{D}-\mathbf{W}$ is 2.07 and in Model-II, $\mathbf{R}^{\mathbf{2}}$ is $\mathbf{0 . 9 8}$ and $\mathbf{D}-\mathbf{W}$ is $\mathbf{2 . 2 9}$ in which State Public Expenditure is independent variable. It proves that there is Bi-variate causal relationship between State Per Capita Income (SPCIG) and State Public Expenditure in Gujarat Economy System.

\section{References:}

[1] Hirway, Indira ((2000) "Dynamic Development in Gujarat: Some Issues", The economic and Political Weekly, august 26, September 2, 2000 Vol. 35(35 and 36), pp. 3106-3120.

[2] Dhokakia. Ravendra (2000): "Liberalization in Gujarat: Review of Recent Experience", The Economic and Political Weekly, August 26, September 2, 2000 Vol. 35(35 and 36), pp. $3121-3124$

[3] Mathur, Niti and S.p. Kayshap (2000): "Agriculture in Gujarat; Problems and Prospects", The Economic and Political Weekly, August 26, September 2, 2000 Vol. 35(35 and 36), pp. 3137 - 3146

[4] Parthasarathy, p. (2000): "Participatory Irrigation Management in Gujarat: Institutional and Financial Issues", The Economic and political weekly, August 26, September 2, 2000 vol. 35(35 and 36), pp. $3147-3154$.

[5] Poulomi Roy (1997), "public capital and growth in a decentralized agents framework" National Institute of Public Finance and policy volume2, issue 5, pp239-246 January.

[6] Basant, Rakesh (2000): "Economic Diversifications in Rural Areas: A Review of processes with Special Reference to Gujarat", working paper no. 0; Gujarat Institute of Development Research-Gota, Ahmedabad 380060.

[7] Mahesh P. Bhatt and Ramesh M. Shah (2000) "Gujarat State Finance Commission", Implications of Recommendations", JSTDR Economic and political weekly, June 10.

[8] Kundu, A, (2000), "Globalising Gujarat Urbanization, Employment and poverty” Economic and political weekly, pp.3172 - 3182, Gujarat, India, August 26 Sept.

[9] Dinesh N.A, (2000), "Recent changes in Gujarat Industry Issues and evidence" economic and political weekly pp $3183-3192$ August 26-September.

[10] Darshini, M., (2000), "Health for all in Gujarat is it achievable" Economic and Political Weekly, pp.3193 - 3204, Gujarat, India, August 26 - September -2. 